https://nv.nltu.edu.ua

https://doi.org/10.36930/40300416

$@ \bowtie$ Correspondence author

Article received 17.09.2020 p.

Article accepted 05.08.2020 p.

Yu. N. Mandro

UDC 574:630.16

yurii.mandro@ukr.net

Ю. Н. Мандро, І. В. Давидова

Державний університет "Житомирська політехніка", м. Житомир, Украӥна

\title{
ПЕРСПЕКТИВИ ЗАСТОСУВАННЯ ДЕРЕВНОГО ВУГІЛЛЯ (БІОЧАРУ) ЯК ЕФЕКТИВНОГО КОНТРЗАХОДУ ДЛЯ РАДІОАКТИВНО ЗАБРУДНЕНИХ І ДЕГРАДОВАНИХ ЛІСОВИХ ЕКОСИСТЕМ
}

\begin{abstract}
Описано власні експериментальні дослідження та проаналізовано наукові праці інших дослідників, що, в підсумку, дає розуміння необхідності дослідити деревний попіл (отриманий за технологією біочару) як унікального й водночас універсального засобу ремедіації порушених, деградованих територій, підвищення ефективності лісокористування. Особливо актуальними майбутні дослідження можуть бути для територій, що зазнали радіоактивного забруднення. Протирадіаційна ефективність деревного вугілля або біочару мало досліджена, оскільки на момент написання статті, не вдалось знайти жодної інформації про подібні роботи. У цьому дослідженні визначено добрива ( $\mathrm{KCl}$, деревний попіл, деревне вугілля, біочар), які покращують або можуть покращити фітосанітарний стан лісів, а також протидіяти міграції радіонуклідів у системі грунт - рослина. Оцінено ступінь впливу таких добрив на лісову флору. Описано досвід застосування деревного вугілля та біочару (ці поняття іноді можуть бути синонімами) для покращення якості грунту та відновлення лісових екосистем. Експериментально перевірено та порівняно вплив калійного добрива, "чистого" деревного попелу та "забрудненого ${ }^{137} \mathrm{Cs} "$ деревного попелу на перехід радіоцезію із грунту в лісові рослини. Результати досліду вказують на те, що внесення чистого або забрудненого деревного попелу у лісові (підкислені) грунти є ефективнішим контрзаходом, ніж внесення КСl. Основна перевага деревного попелу - відсутність хлору. Деревне вугілля ж за низкою параметрів має переваги над деревним попелом i, відповідно, може бути ще ефективнішим контрзасобом. З'ясовано, що деревне вугілля покращує якість грунту на тривалий термін (сотні - тисячі років), сприяє лісовідновленню та лісозбереженню, може бути одним з найперспективніших контрзаходів на радіоактивно забруднених територіях. Ми припускаємо, що весь корисний потенціал деревного вугілля досі не розкрито, а подальші його дослідження сприятимуть ефективнішому використанню. Застосування деревного вугілля у лісових екосистемах, на нашу думку, дасть змогу пом'якшити негативний вплив глобального потепління і техногенних змін, підвищити стійкість екосистем, сприятиме відновленню порушених фітоценозів та зменшенню концентрації деяких парникових газів $\left(\mathrm{CO}_{2}\right.$, сполуки азоту) у повітрі.
\end{abstract}

Ключові слова: лісовідновлення; лісозбереження; ремедіація територій; радіоактивне забруднення; KCl; біодобрива.

\section{Вступ}

Глобальне потепління, зумовлене парниковим ефектом, дедалі сильніше впливає на навколишнє середовище. Природні та, особливо, штучні екосистеми деградують не встигаючи адаптуватись до змін. Додатковий тиск чинить промисловість і техногенні аварії. На території українського Полісся, яка у дорадянські часи була заболоченою, почали з'являтись ознаки дефіциту вологи, щораз частіше виникають масштабні лісові пожежі. Дуже складна ситуація склалась на радіоактивно забруднених територіях. Покинуті міста і села за майже 35 років поросли густою рослинністю, ліси потерпають від хвороб та шкідників, нагромаджується сухостій. Після Чорнобильської катастрофи жодні контрзаходи (окрім відстрілу тварин і захоронення "Рудого лісу") у лісах не здійснювали. Вони досі залишаються головними концентраторами радіонуклідів. Пожежі в таких лісах супроводжуються повторним радіоактивним забрудненням навколишніх територій. Значної шкоди завдають незаконні рубки та видобуток корисних копалин (пісок, граніт, бурштин, ін.). За цих умов доцільно впроваджувати заходи лісовідновлення та лісозбереження. До заходів, що покращують умови лісозростання та протидіють накопиченню рослинами радіонуклідів, належать внесення калійних добрив, деревного попелу, деревного вугілля та біочару. Вплив калійних добрив та деревного попелу неодноразово досліджено, відома їх ефективність як добрива та контрзаходу для іммобілізації ${ }^{137} \mathrm{Cs}$. Деревне вугілля та біочар відомі, як добрива, але їх здатність впливати на міграцію радіонуклідів не вивчено.

Інформація про авторів:

Мандро Юрій Несторович, мол. наук. співробітник, кафедра екологіï. Email: yurii.mandro@ukr.net; https://orcid.org/0000-0003-4621-0719

Давидова Ірина Володимирівна, канд. с.-г. наук, доцент, кафедра екологіï. Email: davydvairina2@gmail.com; https://orcid.org/0000-0001-6535-3948

Цитування за ДстУ: Мандро Ю. Н., Давидова І. В. Перспективи застосування деревного вугілля (біочару) як ефективного контрзаходу для радіоактивно забруднених і деградованих лісових екосистем. Науковий вісник НлтУ України. 2020, т. 30, № 4. С. 92-98.

Citation APA: Mandro, Yu. N., \& Davydova, I. V. (2020). Some prospects for the use of charcoal (biochar) as an effective countermeasure for radioactively contaminated and degraded forest ecosystems. Scientific Bulletin of UNFU, 30(4), 92-98. https://doi.org/10.36930/40300416 
Об'єкт дослідження - добрива, які можуть покращити умови лісозростання.

Предмет дослідження - здатність добрив затримувати міграцію радіонуклідів, сприяти лісовідновленню та лісозбереженню.

Мета дослідження: дослідити ефективність деревного вугілля як універсального добрива та протирадіаційного засобу у радіаційно забруднених i/або деградованих лісових екосистемах.

Для досягнення зазначеної мети потрібно виконати такі основні завдання дослідження: 3-поміж досліджуваних добрив (деревний попіл, $\mathrm{KCl}$, деревне вугілля, біочар) визначити те, яке буде ефективно виводити радіонукліди $\left({ }^{137} \mathrm{Cs}\right) 3$ біологічного колообігу, чинитиме загальний позитивний вплив на рослини, буде достатньо зручним для застосування у лісі та найменш шкідливо впливатиме на довкілля на етапах виготовлення і застосування.

Наукова новизна отриманих результатів дослідження: вперше розглянуто деревне вугілля та біочар у ролі контрзасобу для інактивації ${ }^{137} \mathrm{Cs}$ у системі грунт лісові рослини, надано обгрунтування його потенційній ефективності.

Практична значущість результатів дослідження полягає в тому, що вони можуть бути корисними для розроблення рекомендацій із застосування деревного вугілля на територіях, порушених внаслідок впливу природних чи техногенних факторів.

Аналіз останніх досліджень та публікацій. Відомо, що деревний попіл сприяє підвищенню продуктивності як на агроландшафтах, так і в лісах. Його властивості, як добрива, зумовлені вмістом калію у формі поташу $\left(\mathrm{K}_{2} \mathrm{CO}_{3}\right)$ - легкорозчинного у воді і доступного рослинам з'єднання. Окрім цього, попіл містить фосфор, кальцій, магній, сірку, бор, манган та інші необхідні рослинам макро- і мікроелементи, знижує кислотність грунту, покращує фізичну структуру грунту, збільшує доступ кисню в грунт, без якого не зможуть вести життєдіяльність аеробні мікроорганізми і грунтові безхребетні. Деревний попіл (отриманий як побічний продукт господарської діяльності чи утворений контрольованим випалюванням радіоактивно-забрудненого лісу) також спричиняв довготривалий ефект зниження переходу ${ }^{137}$ Cs $з$ грунту в лісові рослини $[15,18]$.

Щодо калійних добрив трапляється суперечлива інформація. 3 одного боку, калій відіграє важливу роль у житті рослин. Найбільше його в молодих зростаючих органах, клітинному соку рослин, він сприяє швидкому накопиченню вуглеводів. Калій посилює використання аміачного азоту під час синтезу амінокислот та білку. Під впливом калію підвищується зимостійкість рослин. 3 іншого боку, значний вміст хлору в багатьох калійних добривах негативно впливає на ріст і розвиток рослин. Великі дози калійних добрив можуть підвищити концентрацію хлорид-іонів (підкислення грунту), витіснити кальцій і магній із грунтового вбирного комплексу, а також посилити їх міграцію по профілю грунту. Водночас для інактивації цезію потрібно збільшувати дози калійних добрив. Калій здатний витісняти цезій під час засвоєння елементів живлення кореневою системою. Відомо, що разове внесення калійних добрив (100 кг/га діючої речовини калію) у лісових екосистемах сприяє зниженню концентрації ${ }^{137} \mathrm{Cs}$ у рослинах вересу, брус- ниці та чорниці уже в перший рік після внесення [21]. Дослідження, здійснені у Фінляндії та на Маршалових островах, які стосувалися хвойних і тропічних фруктових порід, підтверджують позитивний ефект калійних добрив [1, 20].

Позитивний ефект калійного добрива спостерігається як у коротко-, так і в довгостроковій перспективі. M. Strandberg та M. Johansson показали, що застосування К (10 кг/га) зменшило концентрацію ${ }^{134} \mathrm{C}$ у пагонах вересу за короткий термін (8 місяців) приблизно на $49 \%$ [23]. L. Aro та A. Rantavaara на заході Фінляндії спостерігали як короткострокові, так і довгострокові ефекти від удобрення К у сосновому лісі. У фінському дослідженні концентрація ${ }^{137} \mathrm{Cs}$ у сосновій хвої помітно знижувалась упродовж 1-21 років після застосування калійних добрив [1]. Також давно відомий позитивний ефект додавання у грунт деревного вугілля. Особливу увагу наприкінці XX ст. привернули ділянки незвичайно родючої землі в басейні річки Амазонка (Перу), яку індіанці прозвали Terra Preta (ісп. - Чорна Земля) [25]. Проведені хімічний та геологічний аналізи показали, що ці грунти мають спільне (з навколишніми) геологічне походження і відрізняються високим вмістом деревного вугілля (10-30 \%), азоту, фосфору та кальцію $[5,19]$. Радіовуглецевий аналіз показав, що цьому деревному вугіллю близько 2000 років [1]. Вони (ділянки) давали, і зараз дають, хороший урожай навіть без удобрення. Висока продуктивність врожаю є наслідком використання обвугленої біомаси місцевими мешканцями. Вражає також здатність цих родючих грунтів самовідновлюватися, незважаючи на вологий тропічний клімат та швидкі темпи мінералізації [13]. Здебільшого це пояснюють тим, що органічна речовина стабілізується залишками обвугленої біомаси [10].

На думку деяких вчених, саме деревне вугілля - головний компонент, що відповідає за родючість цього грунту. Вугілля, виготовлене 3 деревини (або інших стійких органічних матеріалів) у процесі низькотемпературного піролізу з обмеженою подачею кисню, в разі додавання у бідні грунти дає вуглець, дуже стійкий до мінералізації. На відміну від попелу, який легко змивається дощовою водою, позбавляючи грунт поживних речовин, деревне вугілля зберігає поживні речовини i родючість грунту [2]. Деревне вугілля, виготовлене за низької температури (не стосується трав'янистих рослин), має внутрішній шар, утворений сконденсованими рослинними оліями, що може слугувати поживним середовищем для мікроорганізмів. Окрім цього, завдяки великій пористості та сорбційним властивостям, деревне вугілля надає грунту якісні властивості, серед яких: на $20 \%$ більша вологоутримувальна здатність, міцна фіксація у грунтових агрегатах мінеральних речовин, висока доступність мінеральних речовин для кореневого живлення та підвищена активність мікроорганізмів. Ці властивості дають перевагу над іншими органічними джерелами завдяки довговічності вугілля в грунті $[1,6$, 24].

Особливо цінним виявилось вугілля для арбускулярних мікоризних грибів, які утворюють симбіотичний зв'язок $з$ кореневими волокнами рослин, даючи змогу останнім отримувати більше поживних речовин. Існує припущення, що мікоризні гриби відіграють важливу роль у регенерації Terra Preta [1]. Фінська дослідниця Янна Піткіен виявила, що деревне вугілля сприяє роз- 
витку бактерій. Численні бактерії, які живуть на коренях рослин, виділяють ензими, які здатні розчиняти мінерали грунту. Утворені при цьому іони швидко приєднуються до застиглої смоли деревного вугілля, а рослини вже у міру потреби можуть ці іони з вугілля "знімати" своїми коренями, тобто живитися. У дощових водах багато азоту, який теж не вимивається з грунту, а вловлюється деревним вугіллям. Унаслідок виходить, що такий грунт здатний живити всі рослини без додаткових добрив. Як альтернативу традиційним органічним добривам вдалося створити схожий за властивостями комерційний рослинний вуглецевий продукт під назвою біочар (biochar). Біочар, як і деревне вугілля, виготовляють методом піролізу органічної біомаси. Виготовляють його зазвичай з органічних відходів, таких як деревна стружка, залишки рослин і гній [6].

Відрізняється від вугілля тим, що його компоненти спеціально сформовані та оптимально збалансовані для грунту. Вплив деревного вугілля або біочару на рослини в радіоактивно забруднених лісових екосистемах досі не досліджено, або проводили тільки одиничні дослідження, оскільки не вдалось знайти жодної інформації про них. Зважаючи на фізико-хімічні характеристики, виникає логічне припущення, що деревне вугілля може бути одним з найефективніших органічних добрив для ремедіації та підвищення продуктивності лісових екосистем.

Матеріали та методи дослідження. Для порівняння ефективності різних видів добрив у радіоактивно забрудненому лісі на відстані близько 70 км від ЧАЕС (Базарське лісництво Народицького р-ну Житомирської обл.) було закладено дослід. Дослідні ділянки (200 м ${ }^{2}$ кожна) із щільністю радіоактивного забруднення за ${ }^{137} \mathrm{Cs} 177-355$ кБк/м $\mathrm{M}^{2}\left(5-9 \mathrm{Ki} / \mathrm{\kappa M}^{2}\right)$ розмістили рендомізовано на площі близько 0,6 га. Схему досліду подано 4 варіантами: 1 - контроль (без внесення добрив); 2 - калійні добрива (KCl); 3 - деревний попіл (Ash); 4 радіоактивно забруднений $\left(17,2\right.$ кБк/кг за $\left.{ }^{137} \mathrm{Cs}\right)$ деревний попіл $\left({ }^{137} \mathrm{CsAsh}\right)$, отриманий унаслідок спалення деревини $з$ досліджуваного лісу. Кожен варіант виконано у 4 повторностях. Добрива вносили одноразово методом розсіювання по поверхні грунту вручну у квітні 2012 р. $з$ розрахунку 100 кг/га діючої речовини калію. Вплив добрив визначали на типових для цього типу лісу (дубово-сосновий субір) листяних рослинах: чорниця (Vaccinium myrtillus), брусниця (Vaccinium vitisidaea), дуб (Quercus), горобина (Sorbus aucuparia) та крушина (Frangula alnus). Зразки листя та молодих пагонів досліджуваних рослин відбирали щороку у червні або липні впродовж 2012-2015 рр. Висушену до повітряно-сухого стану подрібнену та ретельно перемішану (гомогенізовану) рослинну масу поміщали у пластмасові місткості (35 або 60 мл) для вимірювання вмісту ${ }^{137} \mathrm{Cs}$. Грунт відбирали металевим пробовідбірником діаметром 57 мм та довжиною робочої частини 150 мм. Повітряно-сухий грунт розмелювали у ступці та просіювали через сито 2 мм, після чого поміщали в такі ж місткості, що й рослини. Вимірювання питомої активності ${ }^{137}$ Cs проводили з використанням HPGe та NaI детекторів. Час вимірювання кожного зразка забезпечував досягнення похибки не більше $5 \%$ і тривав не довше 24 год. Результати вимірювання обробили за допомогою програм Windas, Microsoft Excel та Minitab (Minitab® 16.2.4Inc.). Коефіцієнт переходу (КП) радіоцезію 3 грунту в листя та молоді пагони розраховували за такою формулою:

$$
K \Pi=\frac{A m}{A s},
$$

де: $A m$ - питома активність ${ }^{137} \mathrm{Cs}$ в одиниці сухої маси рослин, (Бк/кг); $A s-$ щільність забруднення грунту ${ }^{137} \mathrm{Cs},\left(\right.$ БК/ $\left./ \mathrm{M}^{2}\right)$.

\section{Результати дослідження та їх обговорення}

Результати досліджень за 2012-2015 рр. показали, що калійне добриво у перший (2012) рік після внесення спричиняє підвищення переходу радіоцезію (12,5$40,8 \%)$ з грунту в молоді пагони всіх рослин, окрім дуба. Починаючи з другого (2013) року інтенсивність переходу радіонукліда стала нижчою на 1,7-50,9 \% порівняно із контролем. Для чорниці за перші 4 роки позитивний ефект (коефіцієнт переходу ${ }^{137} \mathrm{Cs}$ (КП ${ }^{137} \mathrm{Cs}$ ) нижчий за контроль) не виявлено, хоча помітна тенденція до його настання у наступні роки. Для дуба позитивний ефект добрива тривав упродовж усього періоду дослідження (2012-2015 pp.). Зниження КП ${ }^{137} \mathrm{Cs}$ становило 5,9-41,3\%. Внесення деревного попелу спричинило зниження КП $(1,7-47,5 \%)$ для чорниці та брусниці впродовж всього періоду досліджень. Для горобини, дуба та крушини помічено підвищення КП (18,7$34,5 \%$ ) 3 першого року після внесення, яке в подальшому змінювалось періодами підвищення (до 37,5\%) та зниження (до 29,4 \%). Після внесення радіоактивно забрудненого попелу на удобрених ділянках почало істотно знижуватись надходження ${ }^{137} \mathrm{Cs}$ до рослин. Для деяких рослин зниження почалось вже 3 першого року (чорниця - 11,3\%, дуб - 33,5 \%), для решти - 3 наступного. Порівняно із контролем зниження, загалом для всіх рослин, становило 15,2-66,1\% (рисунок).

Обговорення результатів дослідження. Підвищення КП ${ }^{137} \mathrm{Cs}$ для більшості видів рослин після внесення $\mathrm{KCl}$, ймовірно, було наслідком підкислення грунту хлорид іонами. Внаслідок підкислення частина закріплених катіонів ${ }^{137} \mathrm{Cs}$ могла перейти у рухому доступну для рослин форму. Найшвидше на це відреагували рослини 3 поверхневою кореневою системою (чорниця, брусниця). 3 часом стан рівноваги у грунті відновився і негативний вплив іонів хлору змінився позитивним впливом іонів калію. У дуба ж коренева система розташована глибше, відповідно підвищення кислотності було менш відчутним, а калій міг мігрувати по профілю до кореневої системи дуба і впродовж 4 років виступати антагоністом цезію. Внесення деревного попелу мало найкращий ефект для чорниці та брусниці. Для решти досліджуваних рослин ефект був слабо вираженим i змінювався у позитивний та негативний бік. Ця особливість може бути пов'язана з поступовим розчиненням фракцій попелу, що спричиняло зміну $\mathrm{pH}$, закріплення ${ }^{137} \mathrm{Cs}$ у грунтово-вбирному комплексі, збагачення грунту поживними речовинами. Усі ці процеси відбуваються переважно у верхньому грунтовому горизонті, де й розташована коренева система чорниці та брусниці.

Коренева система деревних порід, очевидно, отримувала тільки частину поживних речовин, що з опадами інфільтрувалась у глибші горизонти. Перевага деревного попелу над калійним добривом, особливо на кислих грунтах, полягає у відсутності хлору. Відмінності ефекту чистого та радіоактивного попелу, швидше за 
все, залежать від хімічного складу попелу. Але, як не дивно, результати лабораторних досліджень не показали значної відмінності за основними показниками ( $\mathrm{pH}$ сольове, загальний К та Р). Відмінність була тільки у
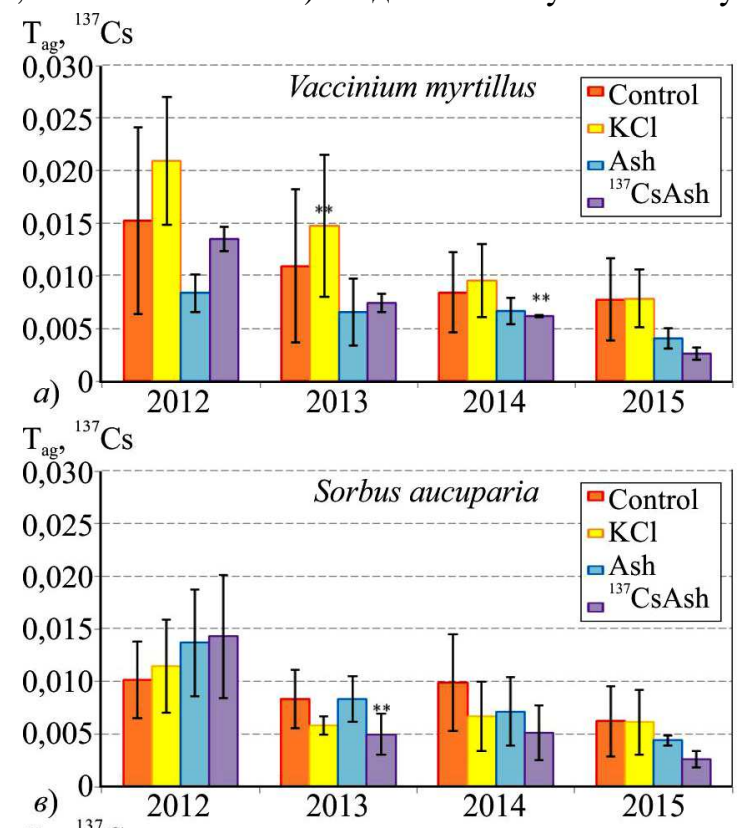

$\mathrm{T}_{\mathrm{ag}},{ }^{137} \mathrm{Cs}$

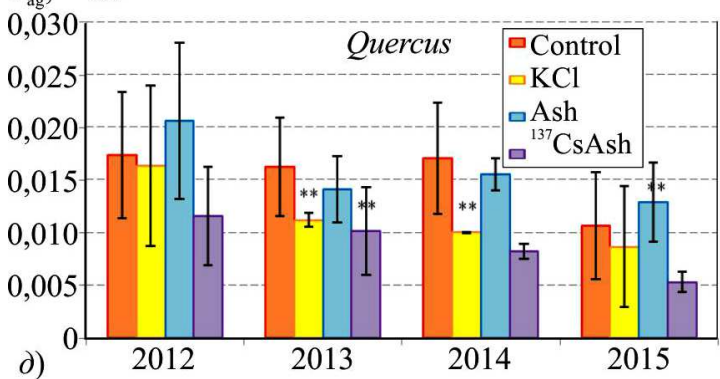

Ми припускаємо, що кращий ефект радіоактивно забрудненого попелу зумовлений краще збалансованими мікро- та макроелементами, адже радіоактивний попіл отримано внаслідок спалення деревини 3 околиць дослідної ділянки. У вигляді попелу в грунт було повернено речовини поглинуті деревом під час росту. За іншим припущенням, у чистому попелі (з меблевої фабрики) вміст К міг бути у рази нижчим порівняно з радіоактивним, оскільки більшу частину асортименту фабрики виготовляли із хвойних порід деревини, тоді як радіоактивний попіл було отримано переважно 3 листяних порід. У попередніх роботах ми показали, що калійне добриво може конкурувати 3 деревним попелом за ефективністю, але комбіноване їх застосування виявилося ефективнішим за будь-яке ( $\mathrm{KCl}$ або $\mathrm{Ash})$ взяте окремо [3]. Експерименти із застосуванням радіоактивно забрудненого попелу та його суміші з калійним добривом показали ще кращий результат. Виявлено, що ${ }^{137} \mathrm{CsAsh}$ - ефективніше за $\mathrm{KCl}$ та Ash знижує надходження цезію у рослини, хоча повна ефективність може проявитись із деяким запізненням (1-2 роки). Комбінація ж ${ }^{137} \mathrm{CsAsh}+\mathrm{KCl}$ виявилась найбільш ефективним добривом. На 3-4 рік після внесення добрива $\left({ }^{137} \mathrm{CsAsh}+\mathrm{KCl}\right)$ для шести видів лісових рослин КП ${ }^{137} \mathrm{Cs}$ був на 39-77 \% нижчим за контрольний [26].

Ми не досліджували вплив калійних добрив та попелу на продуктивність лісових екосистем, оскільки це досить трудомісткий і не точний процес (визначення річної продуктивності лісової фітомаси). Але, грунту- концентрації ${ }^{137} \mathrm{Cs}$. Хоча варто зазначити, що частину чистого попелу, отриманого з меблевої фабрики, не було досліджено на вміст поживних речовин.
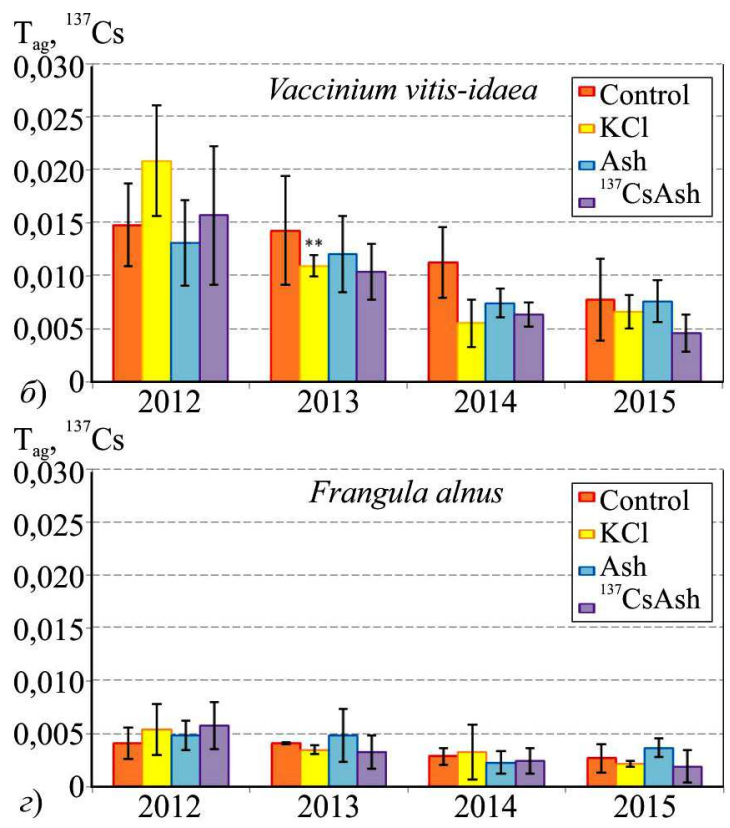

Рисунок. Вплив добрив на перехід ${ }^{137} \mathrm{Cs}$ iз грунту в надземні пагони та листя чорниці (Vaccinium myrtillus), брусниці (Vaccinium vitis-idaea), горобини (Sorbus aucuparia), крушини (Frangula alnus) та дуба (Quercus), $n=3-4, * * n=2$

ючись на багатому досвіді удобрення агроландшафтів, припускаємо, що внесення поживних речовин та деяке підлужнення грунту матиме тільки позитивний ефект. Відомий вплив деревного вугілля на родючість грунту. Наприклад, порівнявши три ділянки тропічного грунту (контроль, хімічні добрива, деревне вугілля + хімічні добрива), врожай на ділянці деревне вугілля + хімічні добрива в 3-4 рази перевершував врожай ділянки 3 просто хімічними добривами. Пористість деревного вугілля збільшує здатність грунту утримувати органічні речовини, воду, інші розчинені поживні речовини [9]. Особливо корисна для лісових екосистем властивість біочару - стимуляція розкладу листяного опаду, що знаходиться в безпосередньому контакті 3 біочаром. Стимуляція може бути спричинена як абіотичними, так і біотичними факторами [16].

Результати окремих досліджень свідчать, що вміст вологи в підстилці збільшується з додаванням біочару, особливо в сухих умовах. Зокрема помічено, що вміст грунтової вологи у помірних лісах Японії зріс на 6-25\% після додавання біочару. Пришвидшений розклад лісової підстилки може бути наслідком збільшення мікробної активності або зміни процесу розкладання внаслідок зміни складу мікробних угруповань. Окрім цього, біочар зазвичай має лужну реакцію $\mathrm{pH}$, що призводить до підвищення $\mathrm{pH}$ (наближення до нейтрального) у разі нанесення на мінеральний шар грунту. Японські дослідження показали, що стара підстилка (під біочаром) посилено розкладалась упродовж 2 років після додавання 
біочару, але нова підстилка (сформована свіжим опадом поверх біочару) посилено розкладалась тільки впродовж одного року (дослід тривав 3 роки). Однак процес розкладання істотно не відрізнявся між новим та старим опадом. Упродовж експериментального періоду викиди вуглецю внаслідок зміни розкладу листяної підстилки були дуже малими порівняно з додаванням вуглецю у складі біочару. Цей результат свідчить про те, що біочар може бути ефективним інструментом для захоплення вуглецю лісовими екосистемами [17]. Дослідження, проведені в Бельгії з лісовими та сільськогосподарськими грунтами, що понад 150 років удобрювались в основному деревним вугіллям, показали, що властивості деревного попелу можуть істотно змінюватись 3 часом, тому тільки довготривалі спостереження дають змогу критично оцінити зміни грунту. Спосіб землекористування чинить значно більший вплив на структуру мікробної спільноти, ніж велика кількість деревного вугілля, присутнього в грунті.

Окрім цього, відсутність взаємозв'язку між деякими видами симбіотичних мікоризних грибів та вуглецем деревного вугілля свідчить про те, що довгостроковий ефект деревного вугілля пов'язаний із зміною екологічної ніші грунту (наприклад, доступність поживних речовин, $\mathrm{pH}$ ), а не зі зміною джерела органічного карбону, доступного біоті. Вуглець деревного вугілля становив близько половини загальної його кількості у лісовому грунті. Викиди $\mathrm{CO}_{2} 3$ лісових грунтів були значно меншими, ніж від суміжних грунтів незалежно від землекористування. Дослідники з Перу, США та Бельгії у спільній роботі визначали приживаність та зростання раннього (Guazuma crinita) та пізнього (Terminalia amazonia) видів дерев під впливом шести різних біочарів у 6-місячному експерименті, проведеному у розпліднику. Розплідник було організовано на бідних мінеральних грунтах, що залишились після нелегального видобування алювіального золота. Приживаність була найвищою внаслідок обробітку грунту біочаром у концентрації 1 т/га, тоді як обробка, що містила добрива або біочар із вмістом 5 т/га, знижувала рівень приживання обох видів порівняно з контролем. Одночасне додавання біочару та добрив призводить до значного збільшення висоти, діаметра, загальної кількості листя, надземної та підземної біомаси обох видів, порівняно з іншими методами оброблення. Оброблення біочаром у концентрації 1 т/га $з$ та без добрива (NPK) показала значно кращі результати, ніж застосування 5 т/га. Більший синергетичний ефект додавання біочару та добрив виявлено для ранніх порід дерев $[7,12,28]$. Спільними зусиллями Бразильських і Нідерландських вчених було виконано метааналіз, у якому поєднали результати 46 досліджень (всі, що були опубліковані у 2000-2014 рр.) стосовно деревного вугілля, біочару та вуглекислого газу [22].

Метааналіз показав, що великі добавки біочару до грунту (співвідношення вуглецю у біочарі до вуглецю у грунті більше 2:1) істотно збільшують викиди $\mathrm{CO}_{2}$, тоді як менша кількість біочару відносно вмісту органічного вуглецю у природних грунтах істотно на викиди не впливає. Робили спроби пов'язати коефіцієнти мінералізації 20 біочарів з їх хімічним складом і виявилось, що біочари з вищими концентраціями білків і цукрів (від неповного перетворення піролізом) характеризуються найбільшими показниками мінералізації. Біочари, що виробляються за вищої температури, призводили до зниження викидів $\mathrm{CO}_{2}$ [8] що, ймовірно, пов'язане зі збільшенням ступеня ароматичності й ароматичної конденсації [11, 27] та відносним зниженням лабільної фракції біочару. Відповідно, застосування біочару має контрастний вплив на біологію грунтів залежно від його кількості та якості, а також від початкових властивостей грунту [14]. Наявні заборони на вирубування та вивезення радіоактивної деревини завадили виготовленню деревного вугілля/біочару та застосуванню його на радіоактивно забруднених територіях. Відповідно, ефект такого удобрення можемо тільки спрогнозувати, опираючись на фізико-хімічні властивості та порівняння $з$ іншими добривами.

Порівняно з деревним попелом, велика пористість та сорбційні властивості деревного вугілля дають змогу краще утримувати вологу, сприяють фіксації поживних речовин та гумусоутворенню. У порах активно заселяються мікроорганізми, що утворюють симбіотичний зв'язок з корінням рослин. Крупніші (порівняно з попелом) фракції краще затримуються у грунті і значно довше справляють ефект удобрення. Оскільки деревний попіл ефективніше за калійні добрива перешкоджає надходженню радіоцезію у лісові рослини, а деревне вугілля в ролі добрива показує кращі за попіл результати, цілком імовірно, що деревне вугілля, або схожий комерційний продукт - біочар, ефективніше підвищуватиме якість грунту i, відповідно, ефективніше протидіятиме надходженню ${ }^{137} \mathrm{Cs}$ у рослини.

\section{Висновки}

3 погляду підвищення родючості, калійні добрива можуть мати швидкий і сильний ефект тільки на лужних і слаболужних грунтах. У лісах же, на кислих і слабокислих грунтах, здебільшого це добриво не є ефективним у короткостроковій перспективі, позитивний ефект проявляється тільки з часом. Деревний попіл, завдяки слаболужній реакції $\mathrm{pH}$, краще підходить як добриво для лісу, але не є зручним для внесення, легко переноситься вітром та водою, може згубно впливати на мікроорганізми. Деревне вугілля та/або біочар, завдяки особливостям будови та складу, можуть істотно покращити якість грунту, чинять істотний і довготривалий (сотні-тисячі років) позитивний ефект, сприяють активізації мікробних угруповань грунту, починаючи 3 першого року після внесення. 3 погляду впливу на міграцію радіонуклідів у системі грунт - рослина, калійні добрива, завдяки іонам хлору, також показали найгіршу ефективність.

Деревний попіл (чистий i забруднений) виявився ефективнішим контрзаходом для більшості рослин, позитивний ефект настає з 1-2 року після внесення. 3 погляду зручності та безпечності виготовлення і застосування, калійні добрива, на нашу думку, є найбільш трудовитратними та шкідливими для довкілля. Деревний попіл простий у виготовленні (найчастіше він $є$ побічним продуктом господарської діяльності), але супроводжується забрудненням атмосфери та не є зручним для транспортування і застосування. Технологія виготовлення деревного вугілля не супроводжується істотним забрудненням атмосфери грунту або води і може вирішити проблему утилізації не придатної до використання (пошкодженої хворобами і шкідниками, радіоактивної, ін.) деревини. 
Виготовлення деревного вугілля у безпосередній близькості до місць санітарних і доглядових рубань (у забруднених і чистих лісах) та внесення цього ж вугілля на лісових кварталах може стати дешевим та ефективним методом лісовідновлення. Виготовлення біочару - процес, зазвичай, більш складний та комплексний порівняно $з$ деревним вугіллям, але придатний для перероблення практично будь-яких органічних відходів і менш шкідливий порівняно 3 калійними добривами. Більш ефективним може бути застосування комбінацій добрив та біочару, оскільки вони мають тривалий синергетичний позитивний вплив на ріст та стійкість саджанців. Результати численних досліджень дають підстави припустити, що біочар може істотно покращити технологію лісовідновлення та лісонасадження завдяки підвищенню продуктивності рослин, істотно зменшивши витрати на утримання, добрива та працю.

Беручи до уваги все зазначене вище, можна зробити обгрунтоване припущення, що деревне вугілля, або виготовлений на його основі біочар, завдяки своїм особливостям (перевагам), може бути ефективним засобом ремедіації радіоактивно забруднених лісових екосистем, відпрацьованих родовищ уранових руд, ділянок, порушених незаконними рубками, видобуванням корисних копалин, техногенними аваріями та ін. Не вдалось знайти інформації про застосування біочару у радіоактивно забруднених екосистемах, достеменно не відомий його вплив на поведінку радіонуклідів. Такі дослідження не проводились або були поодинокими і не відомі у широких колах, тому, на нашу думку, повинні бути виконані/повторені у недалекому майбутньому на територіях, що зазнали радіоактивного забруднення.

\section{References}

1. Добриво з деревного вугілля. (2019). Біопаливо та котли України. Retrieved from: https://bio.Ukr.bio/ua/articles/3267/ (Date of application: 10.12.2019).

2. Документальний фільм. (2002). Режисер: Девід Сінгтон. DOX Productions. Вперше випущений программою Horizon на BBC.

3. Мандро, Ю. ., \& Вінічук, М. М. (2015). Деревний попіл як засіб зниження переходу ${ }^{137} \mathrm{Cs} 3$ грунту в рослини горобини звичайної (Sorbus aucuparia L.) та крушини ламкої (Rhamnus frangula L.) в лісових екосистемах Полісся України. Науковий вісник Східноєвропейського національного університету імені Лесі Українки, 12, 19-25.

4. Aro, L., \& Rantavaara, A. (2011). Long-term effect of fertilization on ${ }^{137} \mathrm{Cs}$ concentration in Scots pine needles. Radioprotection, 46(6), 479-482. https://doi.org/10.1051/radiopro/20116663s

5. Atkinson, C. J., Fitzgerald, J. D., \& Hipps, N. A. (2010). Potential mechanisms for achieving agricultural benefits from biochar application to temperate soils. Plant Soil., 1-18. https://doi.org/10.1007/s11104-010-0464-5

6. Biochar Soil Amendment FAQ. (2019). American public gardens association. website. Retrieved from: https://www.publicgardens.org (Date of application: 15.12.2019).

7. Biochar. (2019). A better start to rain forest restoration. Wake Forest News Wake Forest University. Retrieved from: https://prod.wp.cdn.aws.wfu.edu/assets/biochar.html (Date of application: 15.12.2019).

8. Fabbri, D., Torri, C., \& Spokas, K. A. (2012). Analytical pyrolysis of synthetic chars derived from biomass with potential agronomic application (biochar). Relationships with impacts on microbial carbon dioxide production. Journal of analytical and applied pyrolysis, 93, 77-84. https://doi.org/10.1016/j.jaap.2011.09.012

9. Glaser, B. (2006). Prehistorically modified soils of central Amazonia: a model for sustainable agriculture in the twenty-first cen- tury. Philosophic Transactions Royal Society, 362, 187-196. https://doi.org/10.1098/rstb.2006.1978

10. Glaser, B., Haumaier, L., Guggenberger, G., \& Zech, W. (2001). The 'Terra Preta' phenomenon: a model for sustainable agriculture in the humid tropic. Naturwissenschaften, 88, 37-41. https://doi.org/10.1007/s001140000193

11. Keiluweit, M., Nico, P. S., Johnson, M. G., \& Kleber, M. (2010). Dynamic molecular structure of plant biomass-derived black carbon (biochar). Environmental Science \& Technology, 44, 12471253. https://doi.org/10.1021/es9031419

12. Lefebvre, D., Román-Dañobeytia, F. J., Soete, J., et al. (2019). Biochar Effects on Two Tropical Tree Species and Its Potential as a Tool for Reforestation. Forests, 10(8), 678 p. https://doi.org/10.3390/f10080678

13. Lehmann, J., et al. (2003). Nutrient availability and leaching in an archaeological Anthrosol and a Ferralsol of the Central Amazon basin: fertilizer, manure and charcoal amendments. Plant and Soil., 249, 343-357. https://doi.org/10.1023/A:1022833116184

14. Lehmann, J., Rillig, M. C., Thies, J. E., Masiello, C. A., Hockaday, W. C., \& Crowley, D. (2011). Biochar effects on soil biota a review. Soil Biology and Biochemistry, 43, 1812-1836. https://doi.org/10.1016/j.soilbio.2011.04.022Yu

15. Levula, T., Saarsalmi, A., \& Rantavaara, A. (2000). Effects of ash fertilization and prescribed burning on macronutrient, heavy metal, sulphur and ${ }^{137} \mathrm{Cs}$ concentrations in lingonberries (Vaccinium vitis-idaea). Forest Ecology and Management, 126, 269-279. https://doi.org/10.1016/S0378-1127(99)00110-3

16. Li, Y., et al. (2018). Effect of biochar application in forest ecosystems on soil properties and greenhouse gas emission: a review. $\quad J$. Soils Sediments, 546-563. https://doi.org/10.1007/s11368-017-1906-y

17. Minamino, Y., Fujitake, N., Suzuki, T., et al. (2019). Effect of biochar addition on leaf-litter decomposition at soil surface during three years in a warm-temperate secondary deciduous forest, Japan. Sci Re., 9,16961. https://doi.org/10.1038/s41598-019-53615-2

18. Moilanen, M., Fritze, H., Nieminen, M., et al. (2006). Does wood ash application increase heavy metal accumulation in forest berries and mushrooms? Forest Ecology and Management, 226, 153160. https://doi.org/10.1016/j.foreco.2006.01.033

19. Palviainen, M., et al. (2018). Effects of biochar on carbon and nitrogen fluxes in boreal forest soil. Plant Soil., 71-85. https://doi.org/10.1007/s11104-018-3568-y

20. Robison, W. L., Stone, E. L., Hamilton, T. F., Conrado, C. L. (2006). Long-term reduction in ${ }^{137} \mathrm{Cs}$ concentration in food crops on coral atolls resulting from potassium treatment. Journal of Environmental Radioactivity, 88, 251-266. https://doi.org/10.1016/j.jenvrad.2006.02.007

21. Rosén, K., Vinichuk, M., Nikolova, I., \& Johanson, K. (2011). Long-term effect of a single potassium fertilization on ${ }^{137} \mathrm{Cs}$ levels in plants and fungi in a boreal forest ecosystem. Journal of Environmental Radioactivity, 102(2), 178-184. https://doi.org/10.1016/j.jenvrad.2010.11.009

22. Sagrilo, E., Jeffery, S., Hoffland, E., \& Kuyper, T. W. (2014). Emission of $\mathrm{CO}_{2}$ from biochar-amended soils and implications for soil organic carbon. GCB Bioenergy, 7, 1294-1304. https://doi.org/10.1111/gcbb.12234

23. Strandberg, M., \& Johansson, M. (1998). ${ }^{134} \mathrm{Cs}$ in heather seed plants grown with and without mycorrhiza. Journal of Environmental Radioactivity, 40, 175-184. https://doi.org/10.1016/S0265931X(97)00074-X

24. Terra Preta de Indio. (2008). Soil Biogeochemistry. Johannes Lehmann. Cornell University. Retrieved from: https://web.archive.org/web/20080423103456/http:/www.css.cornell.edu/faculty/lehmann/terra_preta/TerraPretahome.htm (Date of application: 05.12.2019).

25. Terra preta. Wikipedia. (2016). Retrieved from: https://es.wikipedia.org/wiki/Terra_preta (Date of application: 10.12.2019).

26. Vinichuk, M. M., Mandro, Y. N., \& Rozen, K. (2016). The application of mineral fertilizers in order to restore forest ecosystems contaminated with radionuclide ${ }^{137} \mathrm{Cs}$. Агроекологічний журнал, $1,37-41$. 
27. Wiedemeier, D. B., Abiven, S., Hockaday, W. C., Keiluweit, M., Kleber, M., Masiello, C. A., et al. (2015). Aromaticity and degree of aromatic condensation of char. Organic Geochemistry, 78, 135-143. https://doi.org/10.1016/j.orggeochem.2014.10.002
28. Zibold, G., Klemt, E., Konopleva, I. \& Konoplev, A. (2009). Influence of fertilizing on the ${ }^{137} \mathrm{Cs}$ soil - plant transfer in a spruce forest of Southern Germany. Journal of Environmental Radioactivity, 100, 489-496. https://doi.org/10.1016/j.jenvrad.2009.03.011

Yu. N. Mandro, I. V. Davydova

Zhytomyr Polytechnic State University, Zhytomyr, Ukraine

\section{SOME PROSPECTS FOR THE USE OF CHARCOAL (BIOCHAR) AS AN EFFECTIVE COUNTERMEASURE FOR RADIOACTIVELY CONTAMINATED AND DEGRADED FOREST ECOSYSTEMS}

Lack of moisture as a result of global warming causes degradation of forest ecosystems. Unforested areas appear, dryness accumulates, and forest fires become more frequent. Fires in radioactively contaminated forests are followed by re-contamination of surrounding areas. It is possible to improve ecological situation (especially in radioactively contaminated areas) with the application of such fertilizers as wood ash, $\mathrm{KCl}$, charcoal and biochar. The positive effect of "clean" wood ash, radioactively contaminated wood ash, and potassium fertilizer on ${ }^{137} \mathrm{Cs}$ migration in the soil - plant system is shown in the article. $\mathrm{KCl}$ can compete with the efficiency of ash, but their mixture is proved to be more effective than any of them taken separately. Radioactively contaminated ash is proved to be a more effective countermeasure compared to pure ash and $\mathrm{KCl}$. Wood ash is well known to have a positive effect on productivity of forest ecosystems, and the effect of $\mathrm{KCl}$ is ambiguous due to the possibility of additional acidification of the soil. At this stage of the research, it was not possible to make charcoal from radioactively contaminated wood, to investigate it and to check its efficiency. The results of other experimental studies indicate the high efficiency of charcoal as a means to improve the quality or restore the soil. Our research, as well as the work of other researchers, points to the possibility of charcoal and biochar (these terms can be synonymous) to reduce intake of radionuclides into plants. The analysis of the data indicates theoretically (such studies have not been conducted or published yet) greater efficiency of biochar in comparison with some traditional fertilizers (wood ash, $\mathrm{KCl}$ ) on radioactively contaminated soils. The properties of charcoal as a countermeasure in cases of radiation contamination should be investigated experimentally.

Keywords: reforestation; forest preservation; remediation of areas; radioactive contamination; $\mathrm{KCl}$; biofertilizers. 